\title{
FATAL ATTRACTION. THE CLASSICAL PAST AT THE BEGINNING OF THE FRENCH REVOLUTIONARY REPUBLIC (1792-93) ${ }^{1}$
}

\author{
Daniele di Bartolomeo \\ Università degli Studi di Teramo
}

\begin{abstract}
CONTENTS: I. INTRODUCTION: BACK TO THE PAST - II. THE FIRST FRENCH REPUBLICANS FACE-TO-FACE WITH CLASSICAL REVOLUTIONS - III. THE ANCIENTS IN THE CONSTITUTIONAL DEBATE OF YEAR I - IV. CONCLUSION: A TRICK OF FATE
\end{abstract}

\begin{abstract}
The aim of this paper is to investigate the image of the ancient republics in the early months of the French Republic, with particular attention to the debate that preceded the adoption of the Constitution of the Year I (24 June 1793) and to the publications on historical themes discussed or signaled by the press in the summer of 1792. I intend to show how the history of the ancient republics served as a laboratory in which model or simulate the effectiveness of new ideas and concepts, but also as practical guide for those where living through the shocking reality of the revolution.
\end{abstract}

Keywords: French revolution, Constitution, National Convention, Uses of the past, Republicanism

\section{INTRODUCTION: BACK TO THE PAST}

Until recently, the French Revolution was studied with a gaze to the future ${ }^{2}$, toward the new world that it generated and that could only be conceived through the categories that it had created $^{3}$. For this reason, the revolution seemed like a familiar event for those who studied it, one that had little to do with the past or with events that occurred elsewhere in the late eighteenth century ${ }^{4}$. This approach was accompanied by the conviction that the Revolutionaries had chosen the future as a term of comparison for imagining France's regeneration ${ }^{5}$,

1 Translated by Zakiya Hanafi

2 See Rebecca L. Spang, "Paradigms and Paranoia: How Modern Is the French Revolution?", American Historical Review, ${ }^{\circ}$ 108, 2003, pp. 119-147.

3 Keith Michael Baker et al. (eds.), The French Revolution and the Creation of Modern Political Culture, 4 vols., Pergamon Press, Oxford, 1987-1989, 1994; François Furet, La Révolution en débat, Gallimard, Paris, 1999; Michel Biard (ed.), La Révolution française. Une histoire toujours vivante, Tallandier, Paris, 2010; Sophie Wahnich (ed.), Histoire d'un trésor perdu. Transmettre la Révolution française, Les Prairies Ordinaires, Paris, 2013.

4 See Francesco Benigno, Mirrors of Revolution. Conflict and Political Identity in Early Modern Europe, English trans., Brepols, Turnhout, 2009.

5 François Hartog, "La Révolution française et l'Antiquité. Avenir d'une illusion ou cheminement d'un quiproquo?”, in Chrissanthy Avlami (ed.), L'Antiquité grecque au XIXème siècle. Un exemplum contesté?, L'Harmattan, Paris, 2000, pp. 7-46; Avlami, "Le modèle antique à l'épreuve du XVIII siècle. Réflexions sur l'analogie la différenciation et l'Histoire”, in Avlami, Jaime Alvar, Mirella Romero Recio (eds.), Historiographie de l'Antiquité et transferts culturels. Les histoires anciennes dans l'Europe des XVIIe et XIXe siècles, Brill, Amsterdam and New York, 2010, pp. 51-65. 
ignoring current events and definitively emancipating themselves from the past ${ }^{6}$. This position, which still garners support in the wake of Reinhart Koselleck ${ }^{7}$, has since been strongly questioned ${ }^{8}$. Historians have realized that the Revolution did not serve exclusively as a forge for the future: it was also a laboratory where the new took shape through the reuse of discourses about the past and from the past, and through comparison with contemporary experiences ${ }^{9}$.

This radical shift in understanding has opened up new areas for investigation: the topos of the French exceptionality ${ }^{10}$ has been fruitfully challenged $^{11}$, while the Revolution has been reintroduced into its own spatial and temporal perspective ${ }^{12}$. In the last decade especially, many historians have labored to identify the French republican moment ${ }^{13}$, with the aim of extending to revolutionary France the studies on the classical republican tradition begun by John Pocock ${ }^{14}$ and developed variously by Quentin Skinner ${ }^{15}$, Philip Petitt ${ }^{16}$, and many others ${ }^{17}$. However, despite having filled this gap by partially reconstructing French contributions to classical republican discourse, they have overlooked

6 Lynn Hunt, Politics, Culture and Class in the French Revolution, University of California Press, Berkeley, 1984.

7 Reinhart Koselleck, Futures Past. On the Semantics of Historical Time, trans. Keith Tribe, Cambridge, Columbia University Press, Mass., and London, 1985.

8 François Quastana, Pierre Serna, "Le républicanisme anglais dans la France des Lumières et de la Révolution: mesure d'une présence”, La Révolution française [En ligne], $\mathrm{n}^{\circ}$ 5, 2013, mis en ligne le 31 décembre 2013, Consulté le 04 février 2014. URL: http://1rf.revues.org/984.

9 See, for example, Francesco Benigno and Nicoletta Bazzano (eds.) Uso e reinvenzione dell'antico nella politica di età moderna (secoli XVI-XIX), Lacaita Editore, Manduria, Bari, and Roma, 2006 and Manuela Albertone and Antonino De Francesco (eds.), Rethinking Atlantic Word. Europe and America in the Age of Democratic Revolutions, Palgrave, New York, 2009.

10 Michel Vovelle (ed.), Révolution et République. L'exception française, Kimé, Paris, 1994.

11 Annie Jourdan, La Révolution, une exception française?, Flammarion, Paris, 2004.

12 Pierre Serna, "Le Directoire, miroir de quelle République? ”, in Pierre Serna (ed.), Républiques sœurs. Le Directoire et la Révolution atlantique, PUR, Rennes, 2009, pp. 7-20.

13 Raymonde Monnier, Républicanisme, patriotisme et Révolution française, L'Harmattan, Paris, 2005, p. 38. See also: Mona Ozouf, Varennes. La mort de la royauté, Gallimard, Paris, 2005; Jacques de Saint-Victor, Les racines de la liberté. Le débat français oublié 1689-1789, Perrin, Paris, 2007; Andrew Jainchill, Reimagining Politics after the Terror: the Republican Origins of French Liberalism, Cornell University Press, Itacha, N.Y., and London, 2008.

14 John G. A. Pocock, "Cittadini, clienti e creditori: la repubblica come critica del mutamento storico", in Maurizio Viroli (ed.), Libertà politica e virtù civile. Significati e percorsi del repubblicanesimo classico, Edizioni della Fondazione Giovanni Agnelli, Torino, 2004, p. 133; John G. A. Pocock, The Machiavellian Moment: Florentine Political Thought and the Atlantic Republican Tradition, Princeton University Press, Princeton, N.J., 1975.

15 Quentin Skinner, Liberty Before Liberalism, Cambridge University Press, Cambridge, 1998; Martin van Gelderen and Quentin Skinner (eds.), Republicanism: a shared European heritage, 2 vols., Cambridge University Press, Cambridge 2002.

16 Philippe Petitt, Republicanism: A Theory of Freedom and Government, Oxford University Press, Oxford, 1997.

17 Marco Geuna, "La tradizione repubblicana e $i$ suoi interpreti: famiglie teoriche e discontinuità concettuali”, Filosofia politica, $\mathrm{n}^{\circ}$ 1, 1998, pp. 102-132. 
Fatal Attraction. The classical past at the beginning of the French Revolutionary...

many aspects of the Revolutionaries' use of antiquity - precisely because they have worked in the wave of the Cambridge school's approach ${ }^{18}$.

The guiding theme of these studies is almost always the republican discourse: a peculiar, practically invariable set of visions and political solutions that the French republicans used to imagine their republic, as did Machiavelli and the Anglo-American revolutionaries before them. Unlike their predecessors, however, who in one way or another made the most of the principles of the republican tradition, the case of the revolutionaries is viewed at best as a missed opportunity ${ }^{19}$, and at worst as a game of mirrors with tragic consequences. Thus, while the Year I republicans are portrayed as having failed miserably in the attempt to establish a democratic republic because they were obsessed by a certain image of antiquity ${ }^{20}$, those of Year III were purportedly incapable of stabilizing the Republic despite the fact (or perhaps precisely because of the fact) that they drew on a different, more elitist version of classical republicanism ${ }^{21}$. But this is not the place to discuss these questionable interpretations, which reproduce the theme of exceptionality no longer with reference to the French Revolution (that is, a historical event), but with regard to classical republicanism (that is, a historical idiom) ${ }^{22}$.

The aim of this paper is rather to investigate the image of the ancient republics in the early months of the French Republic ${ }^{23}$, with particular attention to the debate that preceded the adoption of the Constitution of the Year I (June $24,1793)^{24}$, and to publications on historical themes discussed or mentioned by the press from the summer of 1792 .

I intend to show that the history of the ancient republics was a guiding landmark for many French revolutionaries: it served as a laboratory to model or simulate the effectiveness of new ideas and concepts; it was a repertoire of events and actors to be used in the political battle as well as a practical guide for those who were living through the shocking reality of the revolution.

18 Christophe Hamel, "L'esprit républicain anglais adapté à la France du XVIIIe siècle: un républicanisme classique?”, in La Révolution française [En ligne], $\mathrm{n}^{\circ} 5,2013$, mis en ligne le 31 décembre 2013, Consulté le 04 février 2014. URL: http://1rf.revues.org/997.

19 Jacques de Saint-Victor, Les racines de la liberté, op. cit., pp. 15-16.

20 Keith Michael Baker, "Transformations of Classical Republicanism in Eighteenth-Century France", The Journal of Modern History, n 73, 2001, pp. 32-53.

21 Jainchill, Reimagining Politics after the Terror, op. cit.

22 On the historiography on the use of the past in the French Revolution, see now Daniele Di Bartolomeo, Nelle vesti di Clio. L'uso politico della storia nella Rivoluzione francese (1787-1799), Viella, Rome, 2014.

23 Michel Biard et al. (eds.), 1792. Entrer en République, Armand Colin, Paris, 2013.

24 Michel Pertué, “Les projets constitutionnels de 1793”, in Révolution et République, op. cit., pp. 174-195; Giuseppe F. Floridia, "Il governo repubblicano nei progetti dei Convenzionali: tableaux di ingegneria costituzionale", Giornale di storia costituzionale, n 10, 2005, pp. 107-130. 


\section{THE FIRST FRENCH REPUBLICANS FACE-TO-FACE WITH THE CLASSICAL REVOLUTIONS}

When the French revolutionaries dethroned Louis XVI25, transforming the monarchy into a republic, most people repudiated the ancient models after a long period of having praised them. It was one thing to declare oneself an admirer of the Romans or the Spartans under a king; it was another to do this in a republic. In the first case, the classical world was distant and irrelevant enough to allow its admirers to use it as they pleased to criticize the monarchical regime and imagine a reform ${ }^{26}$. In the other case, under a republic, it was a matter of actually constructing this alternative - so that the clearly defined and deliberately sugarcoated contours of the ancient republics became more blurred and uncertain. Not that there was any lack of books designed to legitimize the unprecedented republican adventure through the deeds of its classic namesakes. The citizen Bulard, for example, published a work in 1793 that employed the history of ancient and modern republics in order to reassure French republicans as to the feasibility of this grand undertaking. In this text, the author describes the historical paths that have led the peoples of all times from conquest to the loss of liberty. It is a narrative device that Bulard employs not only to explain and justify the topicality of the Revolution, especially the execution of Louis XVI and the proclamation of the Republic, but also to warn the French about their future [FIG. 1].

Bulard's intent, in other words, is to narrate the story and the possible (undesirable) outcomes of the Revolution through the histories of revolutions. In listing the insights and mistakes of ancient and modern republicans, his intention is to advise his fellow citizens on how to build a solid republic and on what the most appropriate remedies should be adopted to prevent the return of monarchy or the advent of anarchy. Otherwise, warns Bulard, the French Republic will struck by the same fate that felled all the republics in the past:

We have just given you a constitution based on the principles of justice. It is up to you to strengthen it by good ways of living, and to consolidate it by the empire of virtue. These are the best bases that it can have. How many republics, failing to be established on these foundations, shone for a few moments with the brilliance of equality, and were followed by eclipses, similar to those meteors that astonish the eye by a sudden flash, and dissipate [... ] May the misfortunes of other Peoples not be lost to us: let us become wise from their mistakes ${ }^{27}$.

25 Marcel Reinhard, La chute de la royauté, Gallimard, Paris, 1969; Michel Vovelle, La chute de la monarchie: 1787-1792, Éditions du Seuil, Paris, 1989; Michael Walzer, Régicide et Révolution. Le procès de Louis XVI, discours et controverses, Payot, Paris, 1989; David P. Jordan, The King's Trial. Louis XVI vs. the French Revolution, University of California Press, Berkeley, 2004; John Hardman, Louis XVI. The silent King, Bloomsbury Academic, London, 2000.

${ }^{26}$ Luciano Guerci, Libertà degli antichi e libertà dei moderni: Sparta, Atene e i 'philosophes' nella Francia del Settecento, Guida, Napoli, 1979; Keith Michael Baker, Inventing the French Revolution. Essays on French Political Culture in the Eighteenth Century, Cambridge University Press, Cambridge, 1990.

27 "Nous venons de vous donner une constitution assise sur les principles de la justice. C'est à vous à l'affermir par de bonnes moeurs, et à la consolider par l'empire de la vertu. Ce sont-là les 
Fatal Attraction. The classical past at the beginning of the French Revolutionary...

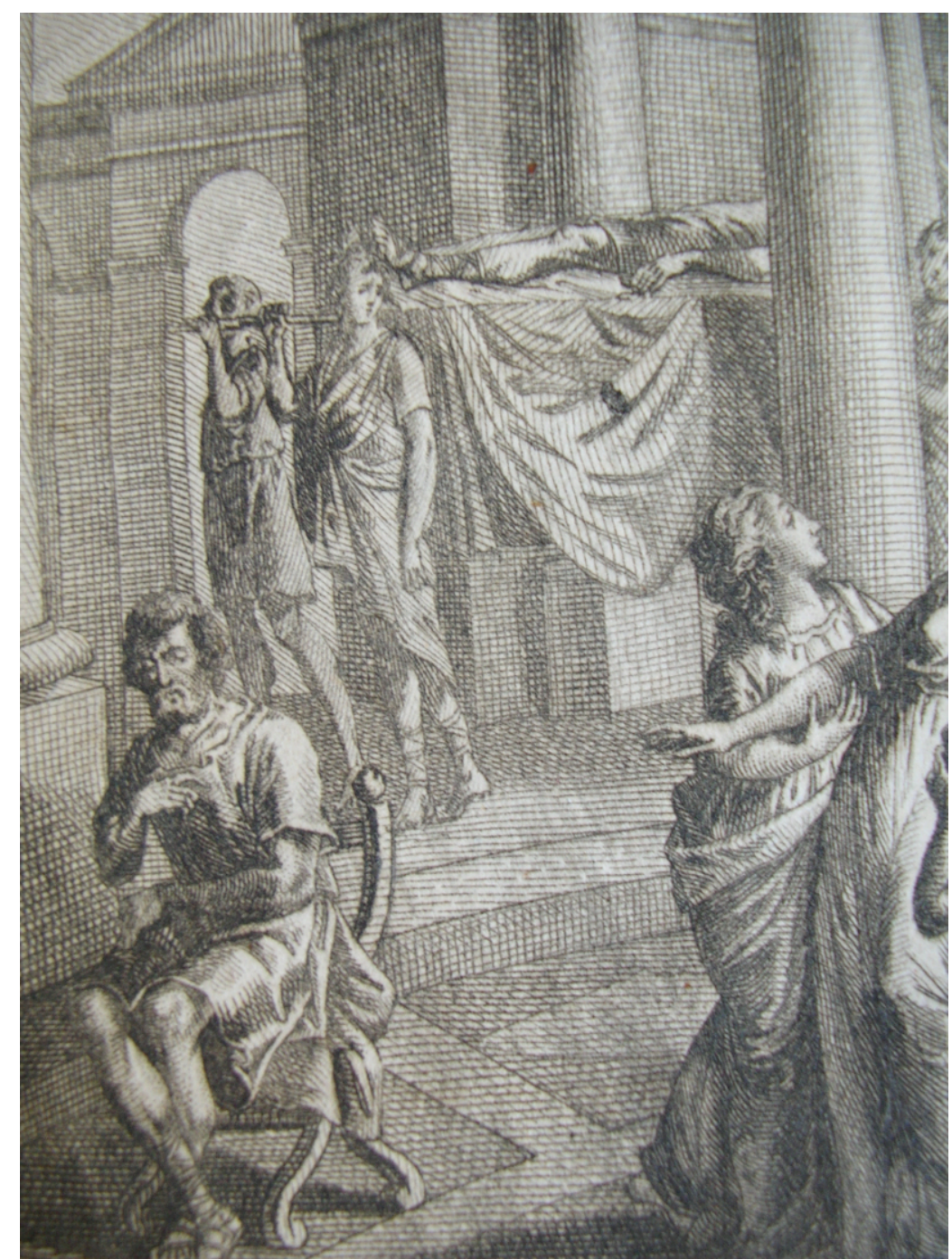

Fig. 1 Brutus condemns his two sons to death, and they were beheaded [Brutus condamne luimême ses deux fils à la mort, et ils eurent la tête tranchée]. Frontispiece of Bulard, Brutus, ou Tableau historique des républiques tant anciennes que modernes, où l'on voit leur origine et leur établissement, ainsi que les causes de leur décadence et de leur ruine; précédé d'Observations sur la réforme de l'ère vulgaire, et du nouveau calendrier: ouvrage propre aux écoles nationales, Paris, 1793.

The imitation of the ancients, therefore, was no longer only a rhetorical opportunity: it was also a concrete problem, which required a new focus. The classical world had to be adapted to the new scenario ${ }^{28}$. Otherwise, unless some proper precautions were taken, they ran the risk of imitating it in every detail, dragging France into the "vicious circle" of state revolutions:

meilleurs bases qu'elle puisse avoir. Que de républiques, faute d'être établies sur ces fondemens, ont brillé quelques momens de l'éclat de l'égalité, et se sont ensuire eclipses, semblables à ces meteors qui étonnent les regards par une clarté subite, et se dissipent [...] Que les malheurs des autres Peuples ne soient pas perdus pour nous: tirons notre sagesse de leurs fautes": Brutus, ou Tableau historique des républiques tant anciennes que modernes, où l'on voit leur origine et leur établissement, ainsi que les causes de leur décadence et de leur ruine, Paris, 1793, pp. 142-143.

28 Luca Scuccimarra, "Sorvegliare e punire. Rivoluzione francese e istituzioni di controllo", Il Pensiero Politico, $\mathrm{n}^{\circ}$ 2, 2007, pp. 434-462. 
An observation that we should make good use of is that the Athenians, the Spartans, and the Romans all began with a monarchy, which only too quickly, as was to be expected, degenerated into despotism - this is the natural course of things - they went on to the aristocratic regime, then they came to democracy, where they remained too short a time, and through anarchy they returned too quickly to the point where they had begun; that is, to tyrants decorated with the titles of kings or emperors ${ }^{29}$.

In September 1792, the author of Les Révolutions de Paris, the famous French revolutionary newspaper, talking about Athens, Sparta and Rome, confidently opined: "They are not a reference model for us". He also added: "We are imitating nobody. Our republic will only have the name of 'republic' in common with the others, both the ancient and the modern ones" 30 . And yet, the term 'republic' was not the only residue of the ancient world to be transferred into the new institutional framework. In the months following the founding of the French Republic, reviews and recommendations of books on the history and the constitutions of the ancient (and modern) republics proliferated in the press ${ }^{31}$. This is because, despite fears about the possibility that France was badly replicating the experiences of the past, or perhaps precisely for this very reason, there were many who thought that history had something to teach. This is what we read in the introduction to a history of the ancient Republics translated from English in 1793:

I sketched the sad picture of the causes that directly or indirectly contributed to the downfall of the ancient republics, to serve us as beacons and to allow us to steer clear, if possible, of the reefs upon which these ancient nations watched their excellent constitutions run aground and perish ${ }^{32}$.

It has been rightly pointed out that the republican discourse revolved around the contingency of political regimes and the means devised and deployed in the

29 "Une observation dont il nous faut profiter, c'est que les Athèniens, les Spartiates et les Romains, tous trois commencèrent par la monarchie, qui ne tarda pas, comme on devoit s'y attendre, par dégénérer en despotisme; c'est le cours naturel des choses; ils passèrent au régime aristocratique, puis ils en vinrent à la démocratie; ils y restèrent trop peu de temps, et retournèrent trop vite, par l'anarchie, au point d'où ils étoient partis, c'est-à-dire, aux tyrans décorés de titres de rois ou d'empereurs": Les Révolutions de Paris, $\mathrm{n}^{\circ}$ 168, du 22 au 29 septembre 1792 , p. 6.

30 "N'ont rien à nous offrir capable de nous servir de règle ou de préservatif [...] à coup sûr nous n'avons point de modèle, nous n'imitons personne [...] cette république dont nous jetons les fondemens [...] n'aura que le nom de commun avec toutes celles qui ont passé et qui existent encore sur la terre": Ibidem.

${ }^{31}$ Louis-Sébastien Mercier, Fragment de politique et d'histoire, Paris, 1792.

32 “J'ai crayonné le triste tableau des causes qui ont directement ou indirectement contribué à la chute des anciennes républiques, pour nous servir comme autant de fanaux, et nous faire éviter, s'il est possible, les écueils contre lesquels ces nations antique ont vu échouer et périr leurs excellentes constitutions": De la naissance et de la chute des anciennes Républiques. Traduit de l'anglais (d'Edward-Wortley Montagu) par le citoyen André-Samuel-Michel Cantwell, Paris, 1793, p. 17. 
Fatal Attraction. The classical past at the beginning of the French Revolutionary...

past for founding them and preventing their decline ${ }^{33}$. This is a homeopathic theory of sorts that viewed the purposive use of the past as the only antidote capable of interrupting the cyclical rhythm of history, perhaps inspired by the famous classical model of the mixed constitution:

At the time of founding a republic that is too big perhaps, in giving it laws, it is only by studying the different constitutions of all the republics of antiquity, and by reviewing the cycle that they went through from their birth until their fall, that our legislators will receive solid instructions. They will see that the most celebrated legislators of antiquity all brought forth mixed governments, or combinations of different powers that balance one another and maintain each other within the limits set by the constitution. They will see that freedom never existed in states where there was only one power, because a single power is always absolute: they will be forced to agree that strictly popular governments have always been the least sustainable, the most prone to factions, and the closest to anarchy ${ }^{34}$.

As this passage makes clear, ancient history was a highly topical genre at the time, a print product whose success was guaranteed. This is something the publishers of the Cercle Social were well aware of: they were a group of activists who (guided by the experience of their ancient predecessors) had long promoted the possibility of establishing a democratic republic in France ${ }^{35}$. It was their idea to print the posthumous works of the well-known classicist Athanase Auger (who had died at the beginning of the 1792) at the end of the year. In introducing the first volume dedicated to The Constitution of the Romans, the Cercle Social described the work as "very important at the moment, when all the nations are reforming their Governments" 36 . This was a discreet, elegant way of reminding the

33 Andrew Jainchill, Reimagining Politics after the Terror, op. cit., p. 6. Speaking about the Constitution of the Year III, taking his cue from Baker's thought, Jainchill has rightly stated that: "They understood the problems facing the French Revolution in classical-republican terms and articulated solutions drawn from the classical-republican repertoire": "The Constitution of the Year III and the Persistence of Classical Republicanism”, French Historical Studies, n 26, 2003 , p. 399.

34 “Au moment de fonder, en lui donnant des loix, une république trop vaste peut-être, ce n'est que dans l'étude des différentes constitutions de toutes les républiques de l'antiquité, et dans l'examen suivi du cercle qu'elles ont parcouru depuis leur naissance jusqu'à leur chute, que nos législateurs pourront puiser de solides instructions. Ils verront que les plus célèbres législateurs de l'antiquité ont tous donné la présence aux gouvernemens mixtes, ou composés de différens pouvoirs qui se balancent et se maintiennent réciproquement dans les limites fixées par la constitution. Ils verront que la liberté n'exista jamais dans les états où il n'y avoit qu'un seul pouvoir, parce qu'un pouvoir unique est toujours absolu: ils seront forcés de convenir que les gouvenemens strictement populaires ont toujours été les moins durables, les plus sujets aux factions, les plus voisins de l'anarchie": "Réflexions et conclusion du Traducteur sur la présente situation de la France, et sur les mesures propres à assurer la durée, la tranquillité et la prospérité de la nouvelle République”, in De la naissance et de la chute des anciennes Républiques, op. cit., pp. 373-374.

35 Gary Kates, The Cercle Social, the Girondins, and the French Revolution, Princeton University Press, Princeton, 1985; Marcel Dorigny, Aux origines de la Républiques, 1789-1792, 5 vols., EDHIS, Paris, 1991.

36 "Très-important dans un moment où tous les peuples s'occupent de la réforme des Gouvernemens": Oeuvres postumes d'Athanase Auger, 10 vols., De la Constitution des Romains sous les rois et aux tems de la République, Paris, 1792, 1, p. 5. 
French that, in spite of the enormous distance that separated them from the republics of antiquity - which were unanimously viewed as incompatible with the France of the late eighteenth century in terms of their territorial extension and social and moral characteristics - the most recent turns taken by the Revolution suggested that they keep the turbulent epic of the ancients, which had never been closer to home than now, uppermost in their minds. The history of Rome and the Greek cities, only recently repeated in the England of Cromwell and the Stuarts, ${ }^{37}$ was both a warning to not repeat the past and a challenge to equal it.

Let us take, for example, the play entitled The Day of Marathon [La Journée de Marathon]. Coming off the presses of the Cercle Social in the summer of 1792, it dramatizes the Athens of Miltiades in its struggle against the Persians under King Darius I. When the theatrical work was reviewed in the Parisian newspapers in July and August of $1792^{38}$, revolutionary France had been at war for some months and the Legislative Assembly had just declared the "fatherland in danger" [la patrie en danger] (July 11). During the same period, the French looked on appalled at the "betrayal" of general La Fayette, who was attempting an unsuccessful military coup to restore Paris to monarchical order. Clearly, then, the story of the Athenians' memorable victory at Marathon (490 A.D.) was no simple literary pastime. Moreover, the author of the play immediately admitted that his intention was not simply to tell the marvelous tale of something that had happened centuries before in ancient Greece:

\begin{abstract}
Remaining as faithful to history as possible, I wanted to provide a model to my fellow citizens by showing them a people in the most desperate of situations, who, while seeing dangers mounting and resources dwindling at every moment, made great, just, and dignified resolutions with all the composure of the courage possessed by those extraordinary men who lived in that age. I believed that there ought to be only one interest in a play of this sort, that of saving the homeland and preserving freedom. I believed that the plot should be very simple and, although the events are pressing, that the action ought to develop slowly and with the dignity of a truly free people who only fear traitors and who are resolved to sacrifice everything rather than fall back into bondage 39 .
\end{abstract}

37 Laurence L. Bongie, David Hume: prophet of the counter revolution (1965), Libery Found, Oxford, 2000; Oliver Lutaud, Des Révolutions d'Angleterre à la Révolution Française. Le tyrannicide et Killing no murder, Martinus Nijoff, La Haye, 1973; Rachel Hammersley, "The Commonwealth of Oceana de James Harrington: un modèle pour la France révolutionnaire?", Annales historiques de la Révolution française, $\mathrm{n}^{\circ} 342,2005$, pp. 3-20; Ead., French Revolutionaries and English Republicans. The Cordeliers Club, 1790-1794, The Boydell and Brewer, New York, 2005.

38 Gazette nationale, ou Le Moniteur universel, 21 vols. (Paris, 1789-1799), 7, $\mathrm{n}^{\circ} 197$ (15/07/1792), p. 824 (hereafter Moniteur); La Chronique du Mois, III, Août 1793, p. 77.

39 “J'ai voulu, en conservant, autant qu'il m'a été possible, la fidélité de l'histoire, offrir un modèle à mes concitoyens en leur montrant un people qui, dans la situation la plus désespérante, voyant à chaque moment ses dangers augmenter et ses resources disparoître, prend avec tout le sang froid du courage des resolutions justes, grandes et dignes des homes extraordinaires qui parurent à cette époque. J'ai cru que, dans une pièce de ce genre, il ne devoit y avoir qu'un seul intérêt, celui de sauver la patrie et de conserver la liberté. J'ai cru que l'intrigue devoit être trèssimple et que, bien que les événemens se pressassent, l'action devoit se developer lentement et avec la dignité d'un people vraiment libre qui ne craint que les traitres et qui est résolu à tout sacrifier plutôt que de retomber dans la servitude": Jean François Guéroult, La Journée de 
Fatal Attraction. The classical past at the beginning of the French Revolutionary...

What we have here, then, is a historical comparison set up specifically to interpret current events and depict their most likely developments. First and foremost, it is the events that precede the defeat of Darius's army on the famous plain of Attica that have something in common with what was happening in France: the tyrannicide of Hipparchus (son and heir of Peisistratos), by the hand of Harmodius and Aristogeiton, and the "hunt" of his brother and successor, Hippias ${ }^{40}$. The author's intention for this episode was to offer his audience a radical reading of the present, which was ultimately also an anticipation of what would happen in the ensuing months. The verses contained in the Day of Marathon represent an indictment against the resolutions put into effect by the court with the complicity of the émigrés-aristocrats and foreign powers who sought to restore monarchical power. The character of Hippias, for example, who tried unsuccessfully to re-enter Athens following Darius's troops, brings to mind both the heads of the counter-revolution - the new "Peisistratids" who wandered Europe in search of allies willing and ready to put an end to the Revolution ${ }^{41}$ - as well as General La Fayette who, having failed in his attempt, on August 19 sensationally surrendered himself to the Austrians.

Nevertheless, the fate of the Athenian tyrant also resonates strongly with the history of Louis XVI: shortly afterwards, the French king was also ousted (August 10, 1792). Likewise, the triumph of the Athenian people resembles that of the revolutionaries, who, a few weeks later, were to beat the Prussians in the unexpected victory of Valmy (September 20): a military success that the press would compare to the greatest victories of the ancients, including that of Marathon. When the play finally debuted at the National Theater in Paris in the summer of 1793, it was clear to everyone that the day of Marathon was a revolutionary day ${ }^{42}$.

There are many other examples that can be shown to be comparing the events taking place in France with those that occurred in the ancient world, juxtaposing the events of the present with the revolutions of the distant past. However, the classicism of the French revolutionaries did not consist solely in a sampling of state revolutions. It was also a history of great constitutions and legendary lawmakers, whose portraits were accordingly reproduced in the Salle

Marathon, ou le Triomphe de la liberté, pièce historique en 4 actes, en prose, avec des intermèdes et des chœurs, Paris, 1792, p. 5.

40 "The scene is in Athens. In the background, the Theater represents a public place. At the sides, on the right, the facade of a temple where there stand statues of Harmodius and Aristogiton. On the left, the portico of a building that we imagine to be the Council Hall [La scène est à Athènes. Le Théâtre représente dans le fond une place publique. Sur les côtés, à droite, la façade d'un temple où sont les statues d'Harmodius et d'Aristogiton. A gauche le portique d'une edifice qu'on suppose être la salle du conseil]": Ivi, p. 6.

41 "The Peisistratids finally came to arm the Persians against the liberty of Athens. For a long time Hippias and his friends traveled around the cities of Greece seeking in vain to drum up hate against us [Les Pisistratides sont enfin pervenus à armer les Perses contre la liberté d'Athènes. Long-tems Hippias et ses amis ont en vain parcouru les villes de la Grèce, cherchant à exciter contre nous la haine]": Ivi, p. 7.

${ }^{42}$ See also François-Nicolas Guillard, Miltiade à Marathon: opéra en deux actes, Paris, 1793. 
$d u$ Manège (Riding Hall) of the Tuileries Palace ${ }^{43}$, the last seat of the National Convention, which was inaugurated in the spring of 1793.

\section{THE ANCIENTS IN THE CONSTITUTIONAL DEBATE OF YEAR I}

The image of the classical world that emerges from the discourses of Year I is highly stylized and ambivalent: if on the one hand it allows the revolutionaries to imagine a free, democratic republic immune from the risk of moral decay and conspiracies, on the other hand, it confronts them with the possibility that an undertaking of this sort may end, as it did then, in failure.

In the minds of the deputies of the National Convention, constructing and maintaining a democratic republic was a difficult, risky affair. The ambiguous memory of the ancients' experience - which seemed both unattainable and unfinished, attractive and repulsive, exemplary and disastrous - was barely attenuated by the recent but still unresolved constitutional experiment of the Americans ${ }^{44}$. To avoid a similar ending, it did not suffice to infuse classical ideas into society and transplant republican institutions into the constitution: the republican legacy also had to be adapted to France. For these reasons, the revolutionaries imagined a republic that should be democratic but not overly so, founded on the principle of representation, but not exclusively. To be both democratic and representative, the French Republic had to depart from the ancients but at the same time keep their mistakes and insights in mind. The words of Durand de Mallaine are emblematic in this regard:

In a free state as large as France, can it occur to anyone to give it the laws of Lycurgus, when in Sparta they lived for nothing but war? Would it be better to give it the laws of Solon, since trade was despised in Athens? Finally, we cannot give it the laws of Rome, where, with the spirit of conquest, they always had patricians. So what course should we take? For many despair of our republic, by its very principles, because of the excessive corruption of manners, and the excessive extent or population of the empire 45.

43 François Boyer, “Les Tuileries sous la Convention”, Bulletin de la Société de l'Histoire de l'Art Française, $\mathrm{n}^{\circ} 1,1934$, pp. 213-218.

${ }^{44}$ Henry E. Bourne, "American Constitutional Precedents in the French National Assembly", The American Historical Review, $\mathrm{n}^{\circ}$ 7, 1903, pp. 466-486; Joyce Appleby, "America as a Model for the Radical French Reformers of 1789", William \& Mary Quarterly, n XXVIII, 1971, pp. 267-286; Denis Lacorne, L'invention de la république: le modèle americain, Hachette, Paris, 1991; Michele R. Morris (ed.), Images of America in Revolutionary France, Georgetown University Press, Washington, 1990; Roberto Martucci (ed.), Constitution \& Révolution aux États-Unis d'Amérique et en Europe, 1766-1815, Laboratorio di storia costituzionale, Macerata, 1995. On the use of ancient history during the American Revolution, see especially the works by Eran Shalev: "Ancient Masks, American Fathers: Classical Pseudonyms during the American Revolution and Early Republic", Journal of the Early Republic, $\mathrm{n}^{\circ}$ 23, 2003, pp. 151-172; Rome Reborn on Western shores. Historical Imagination and the Creation of American Republic, University of Virginia Press, Charlotesville, 2009.

45 "Dans un état libre et aussi vaste que la France, peut-il venir à l'idée de personne de lui donner les lois de Lycurgue, lorsqu'à Lacédémone on ne vivoit que pour la guerre? Peut-on mieux lui donner les lois de Solon, lorsqu'à Athènes on méprisoit le commerce? Enfin, l'on ne peut pas plus lui donner les lois de Rome, où, avec l'esprit de conquete, il y a toujours eu des patriciens. Quel parti donc prendre? Car plusieurs désespèrent de notre république, par ses principes 
Fatal Attraction. The classical past at the beginning of the French Revolutionary...

The modern idea of republic, therefore, had to be refounded on the ruins of the ancient one. How was this to be done? By confronting new problems with ostensibly ancient methods, and by readdressing often only apparently ancient questions with new solutions (possibly dressed up in ancient garb). As the historian Chrissanthy Avlami rightly observed:

Greek history is interpreted in light of a discourse fundamental to the Revolution and fundamentally alien to the Greek polis: the discourse of laws, the discourse on rights, and the debates concerning the mechanisms by which they are to be safeguarded 46

The revolutionaries reinvented Antiquity as an imaginary place that, in the face of the present, made the latter appear either conspicuously superior or deficient. 47 It was an adaptable enough way to test out the effectiveness and durability of the political solutions of modernity. And more. There were some who even believed that the only way the French could avoid succumbing to the same fate as the Greeks and Romans was to resurrect some of the political and moral institutions from the classical world ${ }^{48}$. What this involved were ancient suggestions, remedies conceived or already tried out in the classical world, opportunely reworked and adapted, that were expected to prevent the new political regime from falling into the most likely forms of degeneration: these, too, were deduced by analogy and by contrast, through a comparison between the ancient republics and the French Republic.

The deputies of the National Convention found themselves faced with a twofold, contradictory imperative that required them to prevent the excesses of democracy and to ensure the surveillance of the people's representatives as well as the involvement of citizens in legislative activity. Emblematic in this regard is the title of a speech made by the deputy Charles Lambert dated June 10, 1793: On the revocability of the people's representatives, and more in general, of all the public officers, the only way to obtain a reliable democracy with a representative government, and to prevent the people's revolts [De la révocabilité des représentans du peuple, et en général, de tous les fonctionnaires publics, seul moyen d'avoir une véritable démocratie, avec un gouvernement représentatif, et de prévenir les insurrections populaires]. The theme of popular participation thus underwent a

mêmes, à cause de la trop grande corruption des mœurs, et de la trop grande étendue ou population de l'empire": Pierre Toussaint Durand de Maillane, Examen critique du projet de constitution, présenté à la Convention nationale, par son comité, avec un ordre nouveau dans le plan, le 16 mars 1793, p. 7.

46 Chrissanthy Avlami, "From historia magistra vitae to History as Empirical Experimentation of Progress", in Gabor Klaniczay, Michael Werner and Eight Gecser (eds.), Multiple Antiquities Multiple Modernities. Ancient History in Nineteenth Century European Culture, Campus Verlag, Frankfurt am Main, 2011, p. 146.

47 "Greek democracy serves both as exemplum and, conversely, as proof of the radical novelty introduced by the Revolution: the limited citizenry and pro-slave democracy on the one hand, the 'plenitude of citizens' rights' and thus 'real democracy' on the other": Ivi, p. 151.

48 Luca Scuccimarra, "Rivoluzione francese e istituzioni di controllo", op. cit.; Marcel Gauchet, La Révolution des pouvoirs. La souveraineté, le peuple et la représentation, 1789-1799, Gallimard, Paris, 1995, pp. 80-121. 
transformation from a controversial symbol of democracy for the ancients to a corrective one for the moderns ${ }^{49}$.

This debate on how to modulate the concept of democracy led many of the members of the National Convention into an impasse from which no exit was ever discovered. Their convoluted exercises in constitutional engineering only produced prototypes that were impossible to achieve ${ }^{50}$, crammed with ancient institutions $^{51}$ and designed for radical regeneration of society through the reintroduction of classical educational and military models. ${ }^{52}$ Consider, for example, the institution of censure, which was even envisaged in the draft constitution presented by Condorcet, where it speaks of a "people's censure on acts of national representation". ${ }^{53}$ There were many who reflected on the possibility of introducing an intermediate power into the constitutional framework that would allow the mutual surveillance of society and political power. Still referring to the institution of the censors, for example, the member of the National Convention Jean-François Barailon envisaged that: "They will watch over the intriguers, the conspirators and the agitators and they will bring them to court without any remission" 54 . His colleague Jean Pierre Picqué, on the other hand, drew attention to the ancient laws that obligated "all the citizens to appear in front of the magistrates in charge of surveillance" 55 . Nonetheless, he then cautions that the same institution could turn into a shortcut for usurping power:

49 Daniele Di Bartolomeo, "Abuso delle parole (e della storia) nella Rivoluzione francese: il popolo dell'anno III", in Luca Scuccimarra and Giovanni Ruocco (eds.), Il governo del popolo. Dall'antico regime alla Rivoluzione, Viella, Roma, 2011, pp. 331-355. On the leading role of the people and the use of the concept of the people during the Revolution, see: Gérard Fritz, L'idée de peuple en France du XVIIIe au XIXe siècle, Presses Universitaires de Strasbourg, Strasbourg, 1988; Christian A. Muller, "Du 'peuple égaré' au 'peuple enfant'. Le discours politique révolutionnaire à l'épreuve de la révolte populaire en 1793”, Revue d'histoire moderne et contemporaine, n 47, 2000, pp. 93112; David Andress, Massacre at the Champ de Mars: popular dissent and political culture in the French Revolution. The Boydell Press, New York, 2000; Jon Cowans, To Speak for the People: Public Opinion and the Problem of Legitimacy in the French Revolution, Routledge, London and New York, 2001; Déborah Cohen, La nature du peuple. Les formes de l'imaginaire social, XVIIIe-XXIe siècle, Champ Vallon, Seyssel, 2010.

50 Antoine-Innocent Blaviel, Réflexions préliminaires sur la constitution française et sur l'organisation d'un gouvernement populaire; présentées à la Convention nationale, Paris, le 13 mai 1793.

51 Jacques-Marie Rouzet, Projet de constitution française, Paris, le 18 Avril 1793.

52 Claude-Louis-Michel Desacy, Nouvelles observations sur le plan de Constitution, Paris, 1793, pp. $2-4$.

53 Plan de Constitution présenté à la Convention Nationale, les 15 et 16 Février 1793, p. 31. On Condorcet, see: Keith M. Baker, Condorcet: from Natural Philosophy to Social Mathematics, University of Chicago Press, Chicago, 1975.

54 "Surveilleront [...] les intrigans, les cabaleurs, les pertubateurs, les séditieux et les dénonceront irrémissiblement au tribunal": Jean-François Barailon, Projet de constitution, présenté à la Convention nationale, Le premier juin 1793, p. 41.

55 "Tous les citoyens de se présenter devant les magistrats chargés d'une surveillance sévère, et de punir les oisifs, les intrigans et les calomniateurs,": Nécessité d'établir une censure publique, Paris, june 1793, p. 10. 
Fatal Attraction. The classical past at the beginning of the French Revolutionary...

It has not been forgotten that the Ephori, responsible for maintaining the freedom of the people, appointed annually by the people, soon usurped the executive power for which they should have only acted as moderators. Everybody trembled before this new power; and the senate of Sparta, with no influence, was no longer anything more than a court of law. The history of censure in Rome is no less well-known; in the end it was associated with imperial dignity ${ }^{56}$.

The history books and the broader public debate that took place on the events, institutions, and main characters of the past from the fall of the monarchy to the approval of the Constitution of the Year I refute the widely held belief that the revolutionaries had only a vague knowledge of the classical world57. What we find in these texts, in fact, is an image of Sparta, Athens, and Rome that is not unlike - or at least is no less exact than - the ones provided by Chassebœuf de Volney, Chateaubriand, Constant, and Fustel de Coulanges (to cite the most famous critics of Jacobin classicism) ${ }^{58}$. On these lines, A Glance at Republics by the Parisian deputy Desrues is significant. It clearly depicts a historical representation of the ancient republics, the experience of which is judged to be incompatible, unfinished and, ultimately, disastrous:

Citizens, it is antiquity that must teach us; let us tear away the veil that hides it from us; may great names, may fame, may fickle reputation not beguile us; let us open history up, seek, discover, and grasp the truth [...] It is because peoples were ignorant of Equality that they ended up losing Liberty 59.

To take another example, consider the opening pages of Constitutions of the Spartans, the Athenians, and the Romans published by Pierre-Claude-Bernard Guéroult in 1792. They are dedicated to the Helots - the famous slaves whom the revolutionaries would later be accused of having (inexplicably or cunningly) forgotten. The same argument holds for the agrarian law 60 . In this case, too, the

56 "On n'a pas oublié que les Ephores, chargés de maintenir la liberté du peuple, nommés annuellement par lui, usurpèrent bientôt la puissance exécutrice dont ils n'auroient dû être que les modérateurs. Tout trembla devant ce nouveau pouvoir ; et le sénat de Sparte, sans influence, ne fut plus en effet qu'une cour de justice. L'histoire de la censure à Rome n'est pas moins connue; elle finit par être associée à la dignité impériale": Ivi, p. 18.

57 Luciano Canfora, "Immagini moderne della schiavitù di età classica”, Index, n 8, 1977-78, pp. 104-120; Jacques Godechot, “L’influence de l'antiquité à l'époque de la Révolution”, Index, n 7 , 1977, pp. 45-55; Michel Dubuisson, "La Révolution française et l'Antiquité", Cahiers de Clio, $\mathrm{n}^{\circ}$ 100, 1989, pp. 29-42.

58 Giovanni Paoletti, Ilusione e libertà. Benjamin Constant e gli antichi, Carocci, Roma, 2001; François Hartog, Anciens, modernes, sauvages, Seuil, Paris, 2005.

59 “Citoyens, c'est à l'antiquité à nous instruire ; déchirons le voile qui nous la dérobe; que les grands noms, que la célébrité, que la renommée trompeuse ne nous séduisent pas: ouvrons l'histoire, cherchons, découvrons, saissons la vérité [...] C'est parce que les peuples ont méconnu l'Égalité, qu'ils ont fini par perdre la Liberté": Philippe-François Desrues, Coup d'œil sur les républiques anciennes, Paris, 1794, p. 4.

60 See Reginald B. Rose, "The 'red scare' of the 1790s: the French Revolution and the 'agrarian law”, Past and Present, n' 103 1984, pp. 113-130; Peter M. Jones, "The 'Agrarian Law': schemes for land redistribution during the French Revolution”, Past and Present, n 133, 1991, pp. 96-133; 
revolutionaries' thinking about redistribution of the land almost always concluded with an unequivocal rejection of this normative hypothesis - as if to emphasize that what they had in common with the ancients was not so much the political solutions that they adopted as the sharing of their status as Constituents, as regenerators of society:

Lycurgus, this bold legislator, did he not put forward the fatal agrarian law only when fleeing his country, and lulling the Spartans with the false revelations of the oracle of Delphi [...] This system, the true tombstone of emulation, was not feasible in Sparta, only because all its forces were confined within its walls; and when not warring, its inhabitants lived in idleness; the Helots, their slaves, were the only ones who labored [...] But would this system not outrage our equality in law, and necessity, where 25 million men must live in different places, and work because of the soil and farm products?61.

In short, the deputies of the National Convention seemed compelled to compare themselves to the ancients and to use their nomenclature to provide legitimacy for the new institutional proposals, even at the risk of exposing themselves to criticism from those who might have seen the same historical parallels as proof of certain failure ${ }^{62}$.

To take another example, consider the case of dictatorship ${ }^{63}$. Although it was a well-known fact that the freedom of Rome had ended under the thumb of a dictator, on several occasions Marat invoked the institution of a dictatorship ${ }^{64}$. And even Robespierre succumbed to the temptation of justifying the emergency measures needed to preserve the republic by invoking the classic law that was a not-so-distant alternative to dictatorship, the notorious Senatus consultum

Florence Gauthier, "Loi Agraire”, Dictionnaires des Usages Socio-Politiques (1770-1815), $\mathrm{n}^{\circ} 2$, 1987, pp. 65-98.

61 "Licurgue, ce hardi législateur, n’a-t-il propose la fatale loi agraire qu'en fuyant son pays, et qu'en endormant les Spartiates des révélations mensongères de l'oracle de Delphes [...] Ce systême, tombeau véritable de l'émulation, n'a été practicable à Lacédémone, que parce que toutes ses forces étoient renfermées dans ses murs; qu'hors la guerre, ses habitans vivoient dans la fénéantise; que les Ilotes, leurs esclaves, étoient les seuls qui travailloient [... Mais ce systême ne révolteroit-il pas notre égalité en droit, et la nécessité où sont 25 millions d'hommes d'habiter des lieux différens, et de travailler en raison du sol et des productions?": Antoine-Joseph Thorillon, Idées, ou Bases d'une nouvelle déclaration des droits de l'homme, de celle de ses devoirs et d'une nouvelle constitution pour la République française, Paris, 1793, p. 9.

62 See, for example, the ingenious use of historical comparison practiced by Desmoulins in the pages of his newspaper (Le Vieux Cordelier) during the clash with Robespierre between the end of 1793 and the beginning of 1794: Pierre Vidal-Naquet, La democratie grecque vue d'ailleurs: essais d'historiographie ancienne et moderne, Flammarion, Paris, 1990; Rachel Hammersley, French Revolutionaries and English Republicans, op. cit., pp. 146-158.

63 Luca Scuccimarra and Daniele Di Bartolomeo, "I dilemmi della dittatura. Governo dell'emergenza e patologie del potere nel dibattito rivoluzionario in Francia (1789-1793)", Storia del Pensiero Politico, $\mathrm{n}^{\circ}$ 1, 2012, pp. 11-42.

64 Cesare Vetter, Il dispotismo della libertà. Dittatura e rivoluzione dall'lluminismo al 1848 , Franco Angeli, Milano, 1993; Christian Bruschi, "La dictature romaine dans l'histoire des idées politiques de Machiavel à la Révolution française”, in Michel Gazin (ed.), L'influence de l'Antiquité sur la pensée politique européenne, XVIe-XXe, Presses Universitaires d'Aix-Marseille, Aix-enProvence, 1996, pp. 195-218. 
Fatal Attraction. The classical past at the beginning of the French Revolutionary...

ultimum prepared by the Roman senate in the event of an emergency65. This was until April 6, 1793, when the National Convention created the infamous Committee of Public Safety ${ }^{66}$ between the indignant protests of the Girondins ${ }^{67}$ who were crying out at the advent of dictatorship 68.

Thus, the exhausting race to rethink the foundations of democracy, intended to finally make democracy possible and stable, concluded (as expected) in the worst way: with the confiscation of sovereignty by a faction who ended up approving a democratic and egalitarian constitution that was impossible to apply. For this reason, the constitution of the Year I may be regarded as a monument that the Jacobins unwittingly erected to their own failure, to their inability to resolve the paradox of democracy [FIG. 2].

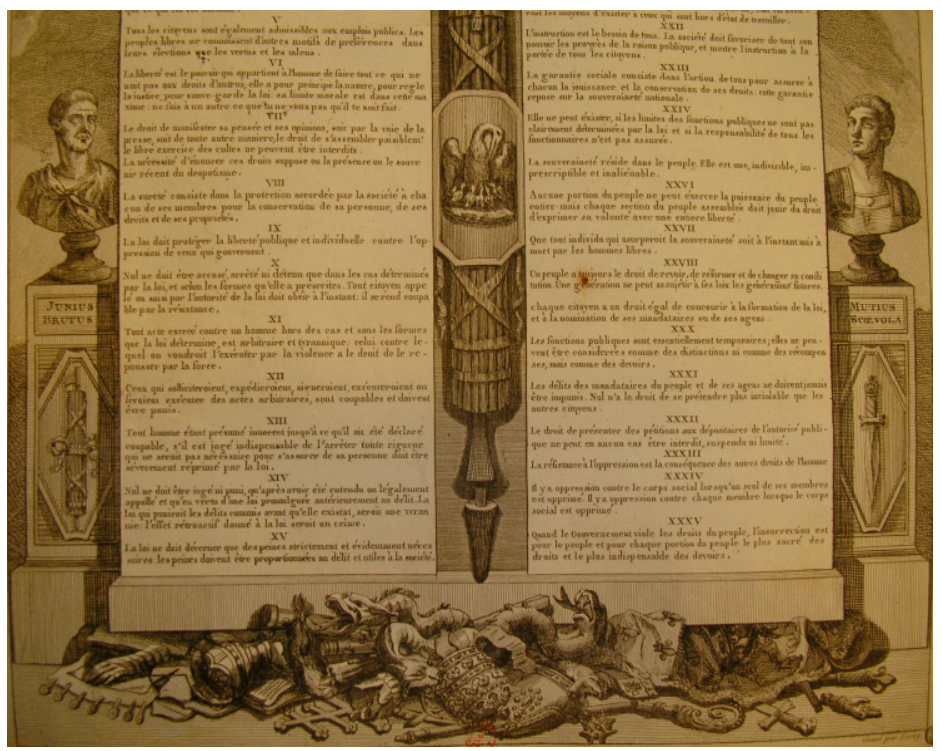

Fig. 2 Jacques Le Roy, Human Rights [Droits de l'homme] (detail) (Paris, [1793]).

65 Moniteur, 7, $\mathrm{n}^{\circ} 311$, Convention Nationale, séance du lundi 5 novembre 1792, p. 1318.

66 Robert R. Palmer, Twelve Who Ruled. The Year of the Terror in the French Revolution, Princeton University Press, Princeton and Oxford, 2005; Bernard Gainot, Dictionnaire des membres du Comité de Salut Public: dictionnaire analytique, biographique et comparé des 62 membres du Comité de Salut Public, Tallandier, Paris, 1990.

67 Michael J. Sydenham, The Girondins, Athlone Press, London, 1961; Alison Patrick, The men of the first French Republic. Political alignments in the National Convention of 1792, The Johns Hopkins University Press, Baltimore and London, 1972; Theodore A. DiPadova, "The Girondins and the Question of Revolutionary Government”, French Historical Studies, $n^{\circ}$ 3, 1976, pp. 432450; Albert Soboul (ed.), Actes du colloque Girondins et Montagnards, Société des Études robespierristes, Paris, 1980; Patrice Higonnet, "The Social and Cultural Antecedents of Revolutionary Discontinuity: Montagnards and Girondins”, The English Historical Review, ${ }^{\circ} 396$, 1985, pp. 513-544; Michael S. Lewis-Beck, Anne Hildreth, Alan B. Spitzer, "Was There a Girondist Faction in the National Convention, 1792-1793?”, French Historical Studies, n 3, 1988, pp. 519536; Frederick A. de Luna, “The 'Girondins' Were Girondins, after All”, French Historical Studies, $\mathrm{n}^{\circ}$ 3, 1988, pp. 506-518; François Furet and Mona Ozouf (eds.), La Gironde et les Girondins, Payot, Paris, 1991.

68 Jerôme Mavidal, et al. (eds.), Archives parlementaires de 1787 a 1860, recueil complet des débats législatifs et politiques des chambres françaises: Première série (1787-1799), 99 vols., Paris, 1867-1995, 61, Convention nationale, séance permanente du samedi 6 avril 1793, p. 374. 
It would fall to the deputies of the Constituent Assembly of Year III ${ }^{69}$ to take up this challenge once again: a challenge that, contrary to common knowledge, was held once again under the banner of creative imitation of the past ${ }^{70}$. But this is another story.

\section{CONCLUSION: A TRICK OF FATE}

Before concluding our discussion on the role of classicism at the beginning of the French Revolutionary Republic, it should be pointed out that this was not the only historical precedent used by republicans and, more generally, by the leaders of the Revolution in order to think about this extraordinary event. Ancient history was certainly not the only touchstone at the disposal of the French revolutionaries. As regards the birth of the Republic, for example, a decisive role was also played by the English revolutions of the seventeenth century and the American Revolution ${ }^{71}$. Similarly, the importance assumed by debates on natural rights and naturalistic metaphors must also be kept in mind ${ }^{72}$. In future studies, other rhetorical spaces that the revolutionaries used to imagine their reality must also be examined. Otherwise, one runs the risk of granting a disproportionate role to a specific political discourse or to a particular historical precedent.

For now, I would like to conclude by recalling that the attempt to draw inspiration from the ancient world that was embarked on by the first French Republicans - which we now understand as reasonable and prudent ${ }^{73}$, but for all that not effective - was interpreted at the time, and especially after Thermidor, as a disastrous attempt at imitation at whose feet the evils of the Revolution could be partly laid ${ }^{74}$. Consider, for example, the debate on republican upbringing and education. In this case, too, despite the bombastic declarations and the approval of the famous, fancifully Spartan education project drafted by the martyr of the Revolution, Le Peletier de Saint-Fargueau ${ }^{75}$, the National Convention never

69 Michel Troper, Terminer la Révolution. La constitution de 1795, Fayard, Paris, 2006.

70 Andrew Jainchill, "Persistence of Classical Republicanism", op. cit., pp. 399-435; Rachel Hammersley, "La France contre l'Angleterre, tout contre, ou lire les texts des républicains anglais au temps du Directoire”, in Républiques sours, op. cit., pp. 205-218.

71 Antonino De Francesco, "Federalist Obsession and Jacobin Conspiracy: France and the United States in a Time of Revolution, 1789-1794", in Rethinking Atlantic Word, op. cit., pp. 239-253; Antonino De Francesco, "Traduzioni e Rivoluzione. La storia meravigliosa della prima versione in francese del Federalist (Paris, Buisson 1792)", Rivista storica italiana, n 1, 2011, pp. 61-110.

72 Marc Belissa et al. (eds.), Républicanisme et droit naturel. Des humanistes aux révolutions des droits de l'homme et du citoyen, Kimé, Paris, 2009; Mary A. Miller, A Natural History of Revolution. Violence, Nature in the French Revolutionary Imagination, 1789-1794, Cornell University Press, Ithaca, N. Y., and London, 2011.

73 Monique Ipotési, Jacobinisme et classicisme, Adriatica Editrice, Bari, 1984.

74 Chrissanthy Avlami, "La Grèce dans l'imaginaire libéral ou, comment se débarrasser de la Terreur”, in L'Antiquité grecque au XIXème siècle, op. cit., p. 75.

75 Joseph Giordani, “L'Antiquité imaginée à travers certains projets d'éducation”, in L'espace et le temps reconstruits. La Révolution française, une Révolution des mentalités et des cultures? Actes du colloque organisé à Marseille le 22, 23 et 24 février 1989, Publication de 1'Université de Provence, Aix-en-Provence, 1990, pp. 131-132; Maxime Rosso, "Les réminiscences spartiates dans les discours et la politique de Robespierre de 1789 à Thermidor”, Annales historiques de la Révolution française, $\mathrm{n}^{\circ}$ 349, 2007, pp. 51-77. 
Fatal Attraction. The classical past at the beginning of the French Revolutionary...

implemented this normative text that Robespierre himself had championed in the assembly. Nevertheless, The Incorruptible and the Jacobins would be accused of having sought to transform Paris into a new Sparta ${ }^{76}$. In this sense, we can say that antiquity was a fatal attraction for the French Republicans: having been picked out along with other examples from the present and the past to tame and legitimize the unprecedented revolutionary undertaking [FIG. 3], it was rocambolesquely turned into the first causal interpretation of the Revolution and its most powerful condemnation [FIG. 4].
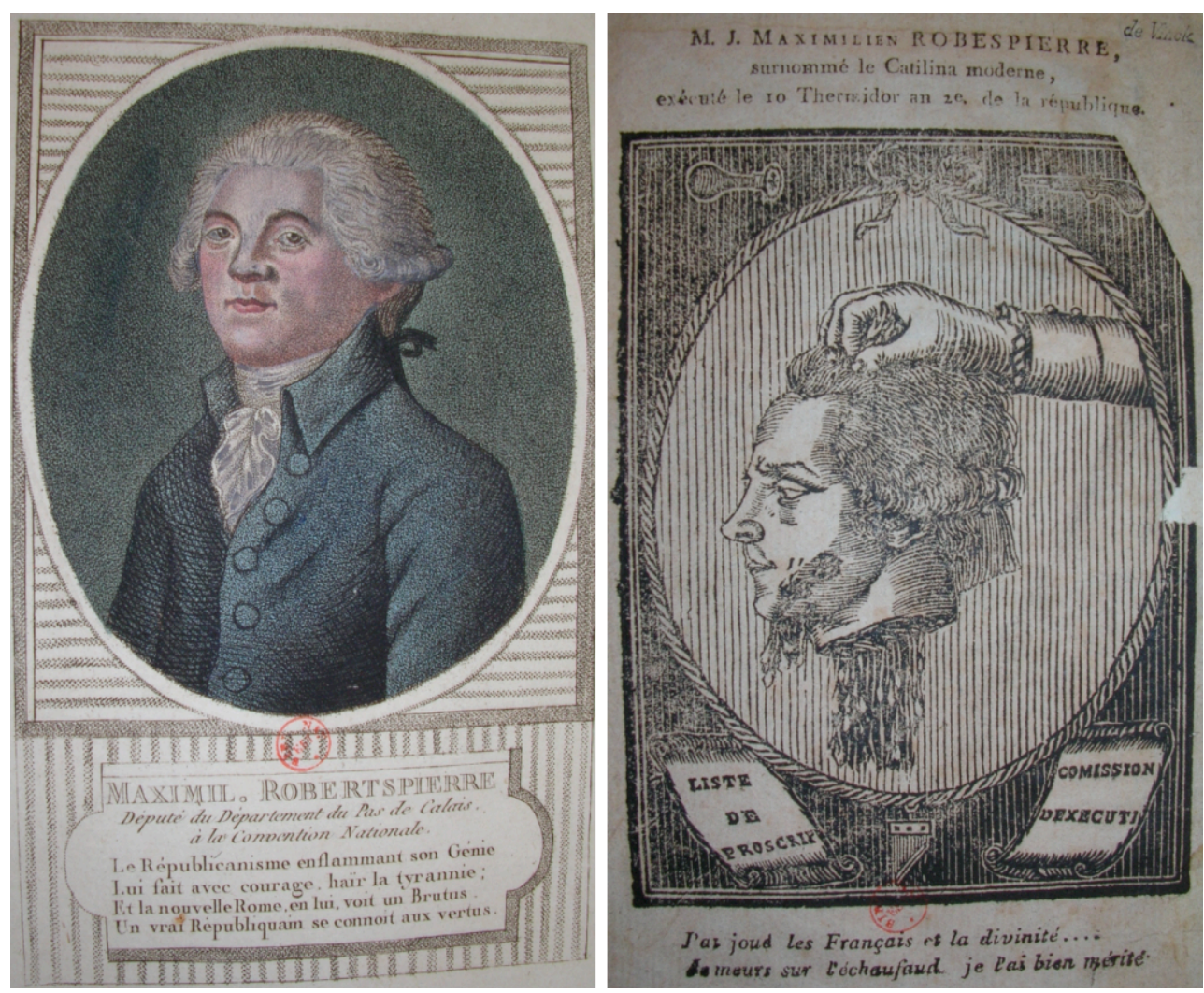

Fig. 3 (on the left) Maximilien Robespierre. Deputy of the Department of Pas-de-Calais, at the National Convention: Republicanism kindling his Spirit / makes him, with Courage, hate tyranny / And the new Rome sees in him a Brutus / A true Republican is recognized by his virtues [Maximil.

Robertspierre. Député du Département du Pas de Calais, à la Convention Nationale: Le Républicanisme enflammant son Génie / Lui fait avec courage, haïr la tyrannie / Et la nouvelle Rome, en lui, voit un Brutus / Un vrai Républicain se connoît aux vertus] (Paris, chez Madame Bergny [1793 or 1794]).

Fig. 4 (on the right) M. J. Maximilien Robespierre: nicknamed the modern Cataline, executed on 10 Thermidor, Year 2 of the Republic [M.J. Maximilien Robespierre: surnommé le Catilina moderne, éxécuté le 10 Thermidor an 2.e, de la République] (Paris, 1794).

Robespierre, who in November of 1792 swore that he would never fall from an accusation of tyranny, in his final moments found himself cursing the spectre of dictatorship:

76 Claude Mossé, L’Antiquité dans la Révolution française, op. cit., pp. 141-153. 
However, this word dictature has magical effects; it withers freedom, it debases government, it destroys the Republic; it degrades all the revolutionary institutions, which are presented as the work of a single individual; it makes odious national justice, which it presents as instituted by the ambition of a single individual; it directs toward this point all the hatred and all the daggers of fanaticism and the aristocracy. What a terrible use the enemies of the Republic have made of the name of a Roman magistracy! 77

The ancient world imagined by the Revolution, like all stories that people imagine ${ }^{78}$, did not exist outside the revolutionaries' own discourse; but this is exactly why it became part of the Revolution. The portrait of the ancients to emerge from the revolutionary debate is first and foremost an invention ${ }^{79}$. And yet, classicism was not entirely at the disposal of its demiurges.

Fecha de envío / Submission Date: 5/05/2015

Fecha de aceptación / Acceptance Date: 18/05/2015

77 "Cependant ce mot de dictature a des effets magiques; il flétrit la liberté; il avilit le gouvernement, il détruit la République; il dégrade toutes les institutions révolutionnaires, qu'on présente comme l'ouvrage d'un seul homme; il rend odieuse la justice nationale, qu'il présente comme instituée par l'ambition d'un seul homme; il dirige sur ce point toutes les haines et tous les poignards du fanatisme et de l'aristocratie. Quel terrible usage les ennemis de la République ont fait du seul nom d'une magistrature romaine!": Discours prononcé par Robespierre, à la Convention nationale, dans la séance du 8 thermidor [...] trouvé parmi ses papiers par la commission chargée de les examiner, in OEuvres de Maximilien Robespierre, 10 vols., Discours, 27 juillet 1793 27 juillet 1794, Presses universitaires de France, Paris, 2000, 10, p. 553. On the fall of Robespierre, see: Françoise Brunel, Thermidor, la chute de Robespierre, 1794, Éditions Complexe, Bruxelles, 1989 and Peter McPhee, Robespierre: a Revolutionary Life, Yale University Press, New Haven and London, 2012.

78 Jacques Rancière, Les mots de l'histoire, Seuil, Paris, 1992.

79 Eric J. Hobsbawm and Terence Ranger (eds.), The Invention of Tradition, Cambridge University Press, Cambridge, 1983. 